\title{
Pengaruh Rasio Keuangan Pada Financial Distress Perusahaan Ritel Yang Terdaftar di Bursa Efek Indonesia (BEI)
}

\author{
Ni Wayan Agustini ${ }^{1}$ \\ Ni Gusti Putu Wirawati ${ }^{2}$ \\ ${ }^{1,2}$ Fakultas Ekonomi dan Bisnis Universitas Udayana (Unud), Bali, Indonesia \\ e-mail: nwagustini@gmail.com
}

\begin{abstract}
ABSTRAK
Penelitian ini bertujuan untuk memperoleh bukti empiris mengenai pengaruh rasio keuangan yakni rasio likuiditas, leverage, profitabilitas, aktivitas, dan pertumbuhan pada financial distress perusahaan ritel yang terdaftar di Bursa Efek Indonesia (BEI). Penelitian dilakukan selama periode 2013-2017 dengan jumlah sampel sebanyak 75 pengamatan yang dipilih dengan metode non probability sampling yaitu purposive sampling. Teknik analisis data yang digunakan adalah analisis regresi logistik. Hasil penelitian membuktikan bahwa rasio leverage berpengaruh positif pada financial distress. Rasio profitabilitas dan rasio aktivitas berpengaruh negatif pada financial distress. Rasio likuiditas dan rasio pertumbuhan tidak berpengaruh pada financial distress.
\end{abstract}

Kata Kunci: rasio keuangan, financial distress, interest coverage ratio

\section{ABSTRACT}

This study aims to obtain empirical evidence regarding the effect of financial ratios, namely liquidity ratios, leverage, profitability, activity, and growth on retail financial distress companies listed on the Indonesia Stock Exchange (IDX). The study was conducted during the period 2013-2017 with a total sample of 75 observations selected by non-probability sampling method, namely purposive sampling. The data analysis technique used is logistic regression analysis. The results of the study prove that leverage ratios have a positive effect on financial distress. Profitability ratios and activity ratios have a negative effect on financial distress. The liquidity ratio and growth ratio have no effect on financial distress.

Keywords: financial ratio, financial distress, interest coverage ratio

\section{PENDAHULUAN}

Suatu perusahaan didirikan dengan tujuan untuk memperoleh laba yang nantinya digunakan untuk mempertahankan kelangsungan hidup usahanya. Dalam menjalankan usahanya, fenomena jatuh bangun merupakan suatu hal yang sudah biasa dihadapi perusahaan. Hal ini disebabkan oleh kondisi perekonomian yang selalu mengalami perubahan sehingga mempengaruhi kegiatan dan kinerja perusahaan, baik perusahaan kecil, menengah maupun perusahaan besar. Jika manajemen tidak mampu mengelola perusahaan dengan baik dan bertahan dalam 
Ni Wayan Agustini dan Ni Gusti Putu Wirawati. Pengaruh...

kondisi ini, maka bayangan penurunan kinerja keuangan bahkan bahaya kebangkrutan akan dihadapi perusahaan (Liana dan Sutrisno, 2014).

Kondisi perekonomian yang berubah-ubah akan sangat berdampak pada berbagai sektor ekonomi khususnya perdagangan eceran (ritel). Bisnis ritel adalah aktivitas bisnis yang mencakup kegiatan usaha menjual barang atau jasa secara langsung kepada konsumen akhir yang digunakan untuk keperluan pribadi, keluarga atau rumah tangga (Utami, 2008: 46). Usaha ritel merupakan peluang besar yang dimiliki Indonesia mengingat sebagian besar masyarakat berpenghasilan dari berjualan barang eceran, namun perusahaan ritel di Indonesia dalam beberapa tahun terakhir banyak yang menutup gerai-gerai ritelnya dengan berbagai alasan.

Salah satu perusahaan ritel yang terkena imbasnya yaitu perusahaan ritel CD musik Disc Tarra yang resmi menutup seluruh gerainya di akhir tahun 2015. Pihak manajemen Disc Tarra menjelaskan bahwa penjualan CD dan DVD terus mengalami penurunan selama lima tahun terakhir, sehingga toko ritel CD musik menjadi tidak diminati lagi seperti masa kejayaannya di awal tahun 2000-an. Selanjutnya pada 30 Oktober 2017, toko ritel perbelanjaan Lotus milik PT. Mitra Adiperkasa (MAPI), yang berlokasi di Thamrin, Jakarta Pusat melakukan penutupan operasional secara total. Pihak manajemen menjelaskan bahwa penutupan ini dikarenakan penghasilan penjualan di toko yang kurang menguntungkan. Masih dibawah naungan MAPI, Debenhams yang merupakan toko ritel asal Inggris pada tahun 2017 juga menutup gerainya di berbagai tempat seperti Supermall Karawaci, Kemang Village dan Senayan City (Pramdia, 2017). 
Masih pada tahun yang sama, salah satu perusahaan ritel ternama yaitu 7 Eleven (SEVEL) dari PT Modern Sevel Indonesia menututup seluruh gerainya pada 30 Juni 2017, hal ini terjadi lantaran adanya beberapa faktor terkait kerugian sebesar Rp 447,9 miliar di kuartal 1 pada tahun 2017. Corporate Secretary PT Modern Putra Indonesia, menyatakan bahwa tutupnya SEVEL disebabkan karena toko tidak mencapai target perusahaan. Pada tahun 2015 pendapatan SEVEL menurun karena situasi ekonomi sedang melemah, terdapat daya saing yang tinggi antar minimarket, serta melemahnya daya beli konsumen sehingga perusahaan mengevaluasi kinerja toko yang tidak mencapai target untuk mengurangi biaya operasional. Selain itu, PT. Matahari Department Store juga menutup dua gerainya di Pasaraya Blok. M dan Pasaraya Manggarai. Menurut pihak manajemen Matahari, penutupan gerai dikarenakan pusat perbelanjaan sepi pengunjung sehingga sudah tidak bisa mencapai target (Ananda, 2017).

Sebuah perusahaan tentunya ingin menghindari kondisi-kondisi yang dapat mengakibatkan kebangkrutan karena dapat mengakibatkan berbagai kerugian baik bagi pemegang saham, karyawan, maupun perekonomian nasional (Al-khatib dan Al-Horani, 2012). Salah satu kodisi yang dapat menempatkan perusahaan dalam bahaya kebangkrutan adalah financial distress. Oleh karena itu, prediksi financial distress merupakan hal yang sangat penting untuk dilakukan perusahaan guna mengantisipasi adanya risiko kebangkrutan yang akan terjadi di masa mendatang. Kegunaan informasi apabila suatu perusahaan mengalami financial distress adalah untuk mempercepat pihak manajemen dalam mengambil tindakan dan melakukan perbaikan serta mencari jalan keluar seperti merger atau take over agar 
Ni Wayan Agustini dan Ni Gusti Putu Wirawati. Pengaruh...

perusahaan lebih mampu untuk membayar hutang dan mengelola perusahaan dengan lebih baik (Hanifah dan Purwanto, 2013). Informasi mengenai kondisi dan kinerja keuangan perusahaan dapat dilihat melalui laporan keuangannya dengan menggunakan analisis rasio keuangan.

Ugurlu dan Aksoy (2006) mengemukakan bahwa kinerja keuangan perusahaan yang sesungguhnya terjadi ditunjukkan dari rasio keuangan. Analisis rasio laporan keuangan juga bisa dijadikan sebagai suatu media untuk memprediksi financial distress yang dihadapi oleh perusahaan (Widhiari dan Merkusiwati, 2015). Menurut Jiming dan Weiwei (2011) rasio keuangan dapat digunakan sebagai indikator pengukur kinerja keuangan perusahaan, yaitu hasil atau kondisi keuangan suatu perusahaan maupun kinerja yang telah dicapai untuk suatu periode tertentu yang disajikan dalam laporan keuangan perusahaan. Hal ini diperkuat dengan hasil penelitian Altman (1968) yang menunjukkan bahwa rasio keuangan dapat bermanfaat untuk memprediksi kegagalan atau kebangkrutan suatu perusahaan dengan tingkat ketepatan prediksi kebangkrutan sebesar 94\% dan $95 \%$ benar dalam penelitiannya. Kondisi keuangan perusahaan perlu di analisis agar tidak sampai terjadi kebangkrutan, analisis ini tidak hanya penting bagi perusahaan tetapi juga bagi pemegang saham, investor, kreditur, pemerintah, karyawan, masyarakat dan manajemen (Zhou et al., 2012). Melalui hasil analisis rasio keuangan ini akan terlihat kondisi kesehatan perusahaan yang bersangkutan. Adapun rasio keuangan menurut Kasmir (2012: 216) yang digunakan untuk memprediksi financial distress yaitu rasio likuiditas, leverage, profitabilitas, aktivitas, dan pertumbuhan. 
Rasio likuiditas merupakan kemampuan suatu entitas untuk melunasi kewajiban lancar perusahaan dengan memanfaatkan aktiva lancarnya. Kewajiban lancar perusahaan dapat berupa hutang yang akan jatuh tempo dalam jangka dekat, upah tenaga kerja, hutang bahan yang dibelinya, pembayaran rekening listrik, air minum yang diperlukan dalam proses produksi, dan sebagainya. Kewajiban tersebut dapat ditutup dari alat-alat likuid yang dimiliki perusahaan. Untuk mempertahankan agar perusahaan tetap dalam kondisi likuid dan terhindar dari financial distress, maka perusahaan harus memiliki dana lancar yang lebih besar dari hutang lancarnya. Penelitian sebelumnya yang dilakukan oleh Widhiari dan Merkusiwati (2015), Sari dan Putri (2016), dan Antikasari (2017) menyatakan bahwa rasio likuiditas berpengaruh pada financial distress yang berarti bahwa semakin likuid suatu perusahaan maka perusahaan akan semakin terhindar dari ancaman financial distress. Sementara itu, penelitian yang dilakukan Sopian dan Putri (2017), Kariani dan Budiasih (2017) serta Dewi dan Dana (2017) menyatakan bahwa rasio likuiditas tidak berpengaruh pada financial distress.

Rasio leverage menunjukkan kemampuan suatu entitas untuk melunasi hutang lancar maupun hutang jangka panjangnya atau rasio yang digunakan untuk menilai sejauh mana suatu entitas dibiayai dengan menggunakan hutang (Wiagustini, 2010: 76). Apabila suatu perusahaan pembiayaannya lebih banyak menggunakan hutang, hal ini berisiko akan terjadi kesulitan pembayaran di masa yang akan datang akibat hutang lebih besar dari aset yang dimiliki. Ketidakmampuan perusahaan dalam memenuhi hutangnya pada kreditur saat jatuhh tempo dapat menyebabkan financial distress (Sari dan Putri, 2016). Hal ini 
Ni Wayan Agustini dan Ni Gusti Putu Wirawati. Pengaruh...

sejalan dengan penelitian yang dilakukan oleh Kristanti et al., (2016), Sari dan Putri (2016), Antikasari (2017), Dewi dan Dana (2017) serta Kariani dan Budiasih (2017) yang menyatakan bahwa rasio leverage berpengaruh pada financial distress. Sementara itu, penelitian yang dilakukan Widhiari dan Merkusiwati (2015), Sopian dan Putri (2017), dan Eminingtyas dan Nita (2017) menunjukkan bahwa rasio leverage tidak berpengaruh terhadap financial distress.

Rasio profitabilitas menunjukkan kemampuan perusahaan menghasilkan laba pada satu periode tertentu dalam hubungannya dengan penjualan, total aktiva, maupun maupun modal sendiri. Rasio ini memberikan ukuran tingkat efektivitas dan efisiensi manajemen suatu perusahaan. Dengan adanya efektivitas dari penggunaan aset perusahaan maka akan mengurangi biaya yang dikeluarkan oleh perusahaan sehingga perusahaan akan memperoleh penghematan dan memiliki kecukupan dana untuk menjalankan usahanya. Dengan adanya kecukupan dana tersebut maka kemungkinan perusahaan mengalami financial distress di masa yang akan datang akan menjadi lebih kecil. Penelitian yang dilakukan Noviandri (2014), Lawrence et al., (2015), Dewi dan Dana (2017) serta Antikasari (2017) menemukan hasil bahwa profitabilitas berpengaruh terhadap financial distress perusahaan. Hasil yang berbeda didapat oleh Hidayat dan Merianto (2014) dan Sari dan Putri (2016) yang mengungkapkan bahwa profitabilitas tidak berpengaruh pada financial distress.

Rasio aktivitas adalah rasio yang digunakan untuk mengukur kemampuan perusahaan dalam menggunakan aktiva yang dimilikinya secara efektif. Atas terpakainya aktiva perusahaan untuk aktivitas operasi, maka akan meningkatkan 
produksi yang dihasilkan oleh perusahaan. Produksi yang meningkat diharapkan dapat menaikkan penjualan yang berdampak pada peningkatan laba perusahaan, sehingga memberikan aliran kas masuk bagi perusahaan (Hidayat dan Merianto, 2014). Penelitian yang dilakukan Hidayat dan Merianto (2014), Widhiari dan Merkusiwati (2015), Antikasari (2017) serta Eminingtyas dan Nita (2017) menunjukkan bahwa rasio aktivitas berpengaruh terhadap financial distress. Hasil ini berbeda dengan penelitian yang dilakukan Pervan et al., (2011) dan Kariani dan Budiasih (2017) yang menungkapkan bahwa rasio aktivitas tidak berpengaruh terhadap financial distress.

Rasio pertumbuhan adalah rasio yang menggambarkan kemampuan perusahaan dalam mempertahankan posisi ekonominya di tengah pertumbuhan perekonomian dan sektor usahanya (Kasmir, 2012: 115). Rasio pertumbuhan dalam penelitian ini diukur dengan pertumbuhan penjualan. Pertumbuhan penjualan mencerminkan penerapan keberhasilan investasi perusahaan pada periode yang lalu dan dapat dijadikan sebagai prediksi untuk pertumbuhan perusahaan di masa depan (Puspitawati, 2016). Apabila tingkat pertumbuhan penjualan suatu perusahaan tinggi berarti tercermin kondisi keuangan yang cukup stabil dan jauh dari financial distress, karena terbukti dengan penjualan yang dapat terus bertumbuh (Harahap, 2011: 67). Penelitian yang dilakukan oleh Utami (2015) dan Widhiari dan Merkusiwati (2015) serta Sopian dan Putri (2017) menyatakan bahwa rasio pertumbuhan penjualan berpengaruh pada financial distress. Sementara itu, hasil penelitian Eminingtyas (2017) dan Muflihah (2017) 
Ni Wayan Agustini dan Ni Gusti Putu Wirawati. Pengaruh...

menunjukkan bahwa pertumbuhan penjualan tidak berpengaruh pada financial distress.

Penelitian ini merupakan pengembangan dari penelitian Widhiari dan Merkusiwati (2015) yang membahas mengenai pengaruh variabel rasio likuiditas, leverage, operating capacity, dan sales growth terhadap financial distress pada perusahaan manufaktur di BEI. Dalam penelitian ini, penulis menambahkan variabel rasio profitabilitas karena rasio ini menunjukkan tingkat kemampuan manajemen dalam memperoleh laba yang diharapkan dapat menghindarkan perusahaan dari financial distress. Pengembangan lain yaitu proksi yang digunakan untuk mengukur financial distress dalam penelitian ini adalah Interest Coverage Ratio (ICR). Pengembangan selanjutnya yaitu perusahaan yang menjadi obyek penelitian ini yaitu perusahaan sektor ritel. Ritel berperan penting bagi perekonomian yaitu sebagai pihak akhir dari rantai produksi dengan secara langsung mendistribusikan barang atau jasa pada konsumen akhir. Fenomena bangkrutnya perusahaan ritel selama beberapa tahun terakhir menjadikan sangat penting untuk mengetahui pengaruh rasio keuangan terhadap kondisi financial distress perusahaan ritel.

Financial distress didefinisikan sebagai proses penurunan kondisi keuangan yang dialami suatu perusahaan sebelum terjadinya kebangkrutan ataupun likuidasi (Platt dan Platt, 2002). Financial distress dapat dimulai dari kesulitan likuidasi (jangka pendek) yang merupakan financial distress yang paling ringan sampai ke pernyataan kebangkrutan yang merupakan financial distress yang paling berat (Brahmana, 2007). Whitaker (1999) serta Elloumi dan Gueyie (2001) menyatakan 
bahwa suatu perusahaan dapat dikatakan berada dalam kondisi financial distress apabila perusahaan tersebut mempunyai laba bersih negatif selama beberapa tahun. Menurut Beaveret al., (2010), financial distress juga dapat ditandai dengan ketidakmampuan perusahaan dalam membayar hutang pada saat jatuh tempo. Asquithet al., (1994) menyatakan bahwa kondisi financial distress perusahaan dapat ditunjukkan melalui Interest Coverage Ratio (ICR). Claessens et al., (2003) mendefinisikan perusahaan yang berada dalam financial distress adalah perusahaan yang memiliki Interest Coverage Ratio (ICR) kurang dari 1. ICR merupakan rasio antara laba sebelum bunga dan pajak pada beban bunga.

Rasio likuiditas menunjukkan kemampuan perusahaan dalam memenuhi kewajiban jangka pendeknya. Menurut teori keagenan, keputusan hutang piutang perusahaan berada dibawah kendali agen. Keputusan agen pada masa lalu yang memutuskan untuk melakukan pinjaman atau kredit pada pihak luar perusahaan mengakibatkan adanya kewajiban keuangan yang jatuh tempo pada saat ini. Jika kewajiban keuangan jatuh tempo yang yang dimiliki suatu perusahaan terlalu banyak, maka keadaan tersebut harus cepat ditagani oleh agen karena akan mengakibatkan perusahaan semakin dekat dengan kondisi financial distress.

Likuiditas yang tinggi dapat menunjukkan sinyal yang baik dan positif bagi investor dan kreditur karena perusahaan dianggap telah mampu untuk menutupi kewajiban lancarnya dan dianggap baik untuk pengelolaannya. Hal ini didukung oleh penelitian Widhiari dan Merkusiwati (2015), Sari dan Putri (2016), dan Antikasari (2017) yang menunjukkan bahwa rasio likuiditas berpengaruh negatif pada financial distress yang berarti bahwa semakin likuid suatu 
Ni Wayan Agustini dan Ni Gusti Putu Wirawati. Pengaruh...

perusahaan maka perusahaan akan semakin terhindar dari ancaman financial distress. Berdasarkan uraian tersebut, maka hipotesis yang diajukan dalam penelitian ini yaitu:

$\mathrm{H}_{1}$ : Rasio likuiditas berpengaruh negatif pada financial distress.

Rasio leverage menunjukkan sejauh mana aktiva perusahaan dibiayai dengan hutang. Rasio ini mengukur kemampuan perusahaan dalam membayar seluruh kewajibannya, baik jangka pendek maupun jangka panjang. Berdasarkan teori keagenan, kelangsungan hidup perusahaan dalam hal apakah agen memutuskan untuk melakukan pendanaan dari pihak ketiga atau tidak berada di tangan agen. Jika proporsi hutang yang dimiliki perusahaan terlalu besar, maka perlu dipertanyakan apakah terjadi kesalahan pengambilan keputusan oleh agen dalam mengelola perusahaan atau agen memang sengaja bertindak dengan mementingkan dirinya sendiri.

Leverage yang tinggi dapat digunakan sebagai sinyal oleh kreditur dalam memberi pinjaman, karena besarnya hutang perusahaan dapat memungkinkan perusahaan tidak mampu melunasi hutang-hutangnya saat jatuh tempo. Apabila suatu perusahaan pembiayaannya lebih banyak menggunakan hutang, hal ini berisiko akan terjadi kesulitan pembayaran dimasa yang akan datang akibat dari hutang lebih besar daripada aset yang dimiliki. Pernyataan ini didukung oleh penelitian Sari dan Putri (2016), Antikasari (2017) serta Dewi dan Dana (2017) yang menyatakan bahwa rasio leverage berpengaruh postif pada financial distress. Hasil penelitian tersebut menunjukkan bahwa semakin besar pendanaan suatu perusahaan melalui hutang, maka kemungkinan perusahaan mengalami financial 
distress akan semakin tinggi. Berdasarkan uraian tersebut, maka hipotesis yang diajukan dalam penelitian ini yaitu:

$\mathrm{H}_{2}$ : Rasio leverage berpengaruh positif pada financial distress.

Rasio profitabilitas mengukur tingkat efektifitas manajemen dalam melaksanakan kegiatan operasinya untuk menghasilkan laba. Menurut teori keagenan, kegiatan operasi perusahaan merupakan tugas dari agen. Jika suatu perusahaan mempunyai laba yang tinggi, maka dapat dikatakan bahwa agen berhasil mengambil keputusan terbaik dalam pengelolaan perusahaan. Laba perusahan yang tinggi dapat memberi sinyal positif bagi para investor untuk berinvestasi di perusahaan tersebut.

Rasio profitabilitas dalam penelitian ini diukur dengan ROA yang menunjukkan kemampuan dari modal yang diinvestasikan dalam keseluruhan aset untuk menghasilkan keuntungan. Dengan adanya efektifitas dari penggunaan aset perusahaan maka perusahaan akan memperoleh penghematan dan memiliki kecukupan dana untuk menjalankan usahanya. Kecukupan dana tersebut menyebabkan kemungkinan perusahaan mengalami financial distress akan semakin kecil. Hal ini didukung oleh penelitian Lawrence et al., (2015), Dewi dan Dana (2017) serta Muflihah (2017) yang menemukan hasil bahwa profitabilitas berpengaruh negatif terhadap financial distress perusahaan. Berdasarkan uraian tersebut, maka hipotesis yang diajukan dalam penelitian ini yaitu:

$\mathrm{H}_{3}$ : Rasio profitabilitas berpengaruh negatif pada financial distress.

Rasio aktivitas digunakan untuk mengukur tingkat efektivitas pemanfaatan sumber daya perusahaan guna menunjang aktivitas perusahaan. Menurut teori 
Ni Wayan Agustini dan Ni Gusti Putu Wirawati. Pengaruh...

keagenan, kegiatan pengelolaan perusahaan adalah tanggungjawab agen. Oleh karena itu, agen dituntut untuk dapat memaksimalkan penggunaan aset perusahaan untuk kegiatan operasional agar dapat menaikkan penjualan. Rasio aktivitas dalam penelitian ini diproksikan dengan TATO, yang bertujuan untuk mengukur efektifitas perusahaan dalam mengelola aktivanya.

Semakin tinggi perputaran total aset menggambarkan semakin efektif total aset perusahaan menghasilkan penjualan. Hal tersebut dapat membuat sinyal bagi investor maupun kreditur untuk melakukan investasi dan kreditnya di perusahaan karena perusahaan telah dinilai baik dalam pengelolaan perusahaan. Jika pelaku kegiatan pengelolaan perusahaan tidak bisa memaksimalkan penggunaan aset perusahaan, penjualan perusahaan juga tidak bisa maksimal, sehingga kemungkinan suatu perusahaan mengalami financial distress akan semakin besar. Hal ini didukung oleh penelitian Hidayat dan Merianto (2014), Widhiari dan Merkusiwati (2015), dan Antikasari (2017) yang menunjukkan bahwa rasio aktivitas berpengaruh negatif terhadap financial distress. Berdasarkan uraian tersebut, maka hipotesis yang diajukan dalam penelitian ini yaitu:

$\mathrm{H}_{4}$ : Rasio aktivitas berpengaruh negatif pada financial distress.

Rasio pertumbuhan digunakan untuk mengukur seberapa besar kemampuan perusahaan dalam mempertahankan posisinya di dalam industri dan dalam perkembangan ekonomi secara umum. Menurut teori keagenan, keputusan investasi dan inovasi strategi perusahaan berada di tangan agen, sehingga agen dituntut dapat menjalakan perusahaan dengan baik agar dapat meningkatkan pertumbuhan perusahaan. Rasio pertumbuhan dalam penelitian ini diukur dengan 
pertumbuhan penjualan yang mencerminkan kinerja manajemen suatu perusahaan untuk dapat meningkatkan penjualan dari satu periode ke periode selanjutnya.

Pertumbuhan penjualan yang tinggi dapat meningkatkan pendapatan perusahaan dari hasil penjualan yang terjadi selama periode tertentu. Hal tersebut menjadi sinyal bagi investor maupun kreditur karena pertumbuhan penjualan perusahaan yang tinggi maka akan mempengaruhi aset dan laba perusahaan, sehingga investor dan kreditur tertarik utuk memberikan investasi dan kredit kepada perusahaan. Pertumbuhan penjualan yang tinggi akan menyebabkan laba semakin tinggi sehingga kondisi keuangan menjadi cukup stabil dan memperkecil kemungkinan perusahaan mengalami financial distress. Hal ini didukung oleh penelitian Utami (2015) dan Widhiari dan Merkusiwati (2015) yang menyatakan rasio pertumbuhan penjualan berpengaruh negatif pada financial distress. Berdasarkan uraian tersebut, maka hipotesis yang diajukan dalam penelitian ini yaitu:

$\mathrm{H}_{5}$ : Rasio pertumbuhan berpengaruh negatif pada financial distress.

\section{ETODE PENELITIAN}

Penelitian dilaksanakan pada perusahaan ritel yang terdaftar di Bursa Efek Indonesia (BEI). Data dari perusahaan tersebut diperoleh dengan mengakses situs resmi BEI yaitu www.idx.co.id, www.sahamok.com, dan website resmi dari masing-masing perusahaan. Metode pengambilan sampel dalam penelitian ini adalah non probability sampling dengan menggunakan teknik purposive sampling. Purposive sampling merupakan teknik pemilihan sampel secara tidak acak yang informasinya diperoleh dengan menggunakan kriteria tertentu. Teknik 
Ni Wayan Agustini dan Ni Gusti Putu Wirawati. Pengaruh...

analisis data dalam penelitian ini menggunakan analisis regresi logistik melalui program Statistical Package for Social Science (SPSS). Pengujian hipotesis dilakukan dengan menggunakan analisis regresi logistik karena variabel terikat dalam penelitian ini merupakan variabel dummy serta memiliki variabel bebas lebih dari satu. Adapun persamaan regresi yang terbentuk dalam penelitian ini yaitu sebagai berikut.

$$
\operatorname{Ln} \frac{P}{1-P}=\alpha+\beta_{1} X_{1}+\beta_{2} X_{2}+\beta_{3} X_{3}+\beta_{4} X_{4}+\beta_{5} X_{5}+e
$$

\section{Keterangan:}

$$
\begin{aligned}
& \ln \frac{\mathrm{P}}{1-\mathrm{P}}=\text { Probabilitas financial distress (variabel dummy, } 1 \text { jika } \\
& \alpha=\text { Konstanta regresi } \\
& \beta_{1}-\beta_{5}=\text { Koefisien regresi variabel independen } \\
& \mathrm{X}_{1} \quad=\text { Likuiditas } \\
& \mathrm{X}_{2} \quad=\text { Leverage } \\
& \mathrm{X}_{3} \quad=\text { Profitabilitas } \\
& \mathrm{X}_{4} \quad=\text { Aktivitas } \\
& \mathrm{X}_{5} \quad=\text { Pertumbuhan } \\
& \text { e }=\text { Error }
\end{aligned}
$$

\section{HASIL DAN PEMBAHASAN}

Pengujian statistik deskriptif disajikan untuk memberikan informasi mengenai nilai minimum, nilai maksimum, nilai rata-rata, dan standar deviasi dari masingmasing variabel penelitian. Hasil dari uji statistik deskriptif disajikan pada Tabel 1 sebagai berikut. 
Tabel 1.

Hasil Uji Statistik Deskriptif

\begin{tabular}{lccccc}
\hline & N & Minimum & Maximum & Mean & Std. Deviation \\
\hline X1 & 75 & 0,037 & 14,030 & 2,27723 & 2,522172 \\
X2 & 75 & 0,074 & 16,834 & 1,43012 & 3,135620 \\
X3 & 75 & $-10,889$ & 0,458 & $-0,26904$ & 1,651607 \\
X4 & 75 & 0,081 & 20,425 & 2,53771 & 2,690434 \\
X5 & 75 & $-0,778$ & 11,026 & 0,33064 & 1,353854 \\
Y & 75 & 0 & 1 & 0,24 & 0,430 \\
Valid N (listwise) & 75 & & & & \\
\hline
\end{tabular}

Sumber: Data diolah, 2018

Variabel rasio likuiditas $\left(\mathrm{X}_{1}\right)$ memiliki nilai minimum sebesar 0,037 dan nilai maksimum sebesar 14,030 . Hal ini menunjukkan bahwa nilai terendah dari variabel likuiditas pada perusahaan ritel yang terdaftar di BEI periode 2013-2017 yaitu sebesar 0,037 yang dimiliki oleh PT Trikomsel Oke Tbk, sedangkan nilai tertingginya sebesar 14,030 yaitu dimiliki oleh PT Electroic City Indonesia Tbk. Secara keseluruhan, nilai rata-rata variabel likuiditas sebesar 2,27723 dengan standar deviasi sebesar 2,522172, artinya terdapat penyimpangan antara nilai variabel likuiditas yang telah diteliti dengan nilai rata-ratanya yaitu sebesar 2,522172 .

Variabel rasio leverage $\left(\mathrm{X}_{2}\right)$ memiliki nilai minimum sebesar 0,074 dan nilai maksimum sebesar 16,834. Hal ini menunjukkan bahwa nilai terendah dari variabel leverage pada perusahaan ritel yang terdaftar di BEI periode 2013-2017 yaitu sebesar 0,074 yang dimiliki oleh PT Electroic City Indonesia Tbk, sedangkan nilai tertingginya sebesar 16,834 yaitu dimiliki oleh PT Trikomsel Oke Tbk. Secara keseluruhan, nilai rata-rata variabel leverage sebesar 1,43012 dengan standar deviasi sebesar 3,135620, artinya terdapat penyimpangan antara nilai variabel leverage yang telah diteliti dengan nilai rata-ratanya yaitu sebesar 3,135620. 
Ni Wayan Agustini dan Ni Gusti Putu Wirawati. Pengaruh...

Variabel rasio profitabilitas $\left(\mathrm{X}_{3}\right)$ memiliki nilai minimum sebesar $-10,889$ dan nilai maksimum sebesar 0,458 . Hal ini menunjukkan bahwa nilai terendah dari variabel profitabilitas pada perusahaan ritel yang terdaftar di BEI periode 2013-2017 yaitu sebesar -10,889 yang dimiliki oleh PT Trikomsel Oke Tbk, sedangkan nilai tertingginya sebesar 0,458 yaitu dimiliki oleh PT Matahari Department Store Tbk. Secara keseluruhan, nilai rata-rata variabel profitabilitas sebesar -0,26904 dengan standar deviasi sebesar 1,651607, artinya terdapat penyimpangan antara nilai variabel profitabilitas yang telah diteliti dengan nilai rata-ratanya yaitu sebesar 1,651607.

Variabel rasio aktivitas $\left(\mathrm{X}_{4}\right)$ memiliki nilai minimum sebesar 0,081 dan nilai maksimum sebesar 20,425. Hal ini menunjukkan bahwa nilai terendah dari variabel aktivitas pada perusahaan ritel yang terdaftar di BEI periode 2013-2017 yaitu sebesar 0,081 yang dimiliki oleh PT Centratama Telekomunikasi Indonesia Tbk, sedangkan nilai tertingginya sebesar 20,425 yaitu dimiliki oleh PT Global Teleshop Tbk. Secara keseluruhan, nilai rata-rata variabel aktivitas sebesar 2,53771 dengan standar deviasi sebesar 2,690434, artinya terdapat penyimpangan antara nilai variabel aktivitas yang telah diteliti dengan nilai rata-ratanya yaitu sebesar 2,690434.

Variabel rasio pertumbuhan $\left(\mathrm{X}_{5}\right)$ memiliki nilai minimum sebesar $-0,778$ dan nilai maksimum sebesar 11,026. Hal ini menunjukkan bahwa nilai terendah dari variabel pertumbuhan pada perusahaan ritel yang terdaftar di BEI periode 2013-2017 yaitu sebesar -0,778 yang dimiliki oleh PT Global Teleshop Tbk, sedangkan nilai tertingginya sebesar 11,026 yaitu dimiliki oleh PT Matahari 
Department Store Tbk. Secara keseluruhan, nilai rata-rata variabel pertumbuhan sebesar 0,33064 dengan standar deviasi sebesar 1,353854, artinya terdapat penyimpangan antara nilai variabel pertumbuhan yang telah diteliti dengan nilai rata-ratanya yaitu sebesar 1,353854 .

Variabel financial distress (Y) merupakan variabel dummy. Nilai 1 diberikan untuk perusahaan perusahaan ritel yang terdaftar di BEI periode 20132017 yang mengalami financial distress, sedangkan nilai 0 untuk perusahaan ritel yang terdaftar di BEI periode 2013-2017 yang tidak mengalami financial distress. Secara keseluruhan, nilai rata-rata variabel financial distress sebesar 0,24 dengan standar deviasi sebesar 0,430, artinya terdapat penyimpangan antara nilai variabel financial distress yang telah diteliti dengan nilai rata-ratanya yaitu sebesar 0,430.

Kelayakan model regresi dinilai menggunakan uji Hosmer dan Lemeshow. Hasil pengujiannya disajikan pada Tabel 2 sebagai berikut.

Tabel 2.

Hasil Uji Hosmer dan Lemeshow

\begin{tabular}{cccc}
\hline Step & Chi-square & Df & Sig. \\
\hline 1 & 7,711 & 7 & 0,359 \\
\hline Sumber: Data diolah, 2018 & & &
\end{tabular}

Tabel 2 menunjukkan bahwa nilai dari Chi-square sebesar 7,711 dengan nilai signifikansi sebesar 0,359 . Berdasarkan hasil pengujian tersebut, nilai signifikansinya lebih besar dari 0,05 sehingga disimpulkan bahwa model mampu memprediksi nilai observasinya atau dengan kata lain model dapat diterima karena cocok dengan data observasinya.

Pengujian untuk menilai keseluruhan model dilakukan dengan membandingkan antara nilai -2 Log Likelihood (LL) pada block number $=0$ 
Ni Wayan Agustini dan Ni Gusti Putu Wirawati. Pengaruh...

dengan nilai -2 Log Likelihood (LL) pada block number = 1. Hasil pengujiannya disajikan pada Tabel 3 sebagai berikut.

Tabel 3.

Perbandingan Nilai -2LL Awal dengan Nilai -2LL Akhir

\begin{tabular}{cc}
\hline -2LL awal (Block Number $=0)$ & 82,662 \\
\hline -2LL akhir $($ Block Number $=1)$ & 32,849 \\
\hline Sumber: Data diolah, 2018
\end{tabular}

Tabel 3 menjelaskan nilai -2LL awal yaitu sebesar 82,662 dan nilai -2LL akhir mengalami penurunan menjadi 32,849. Penurunan nilai -2LL tersebut menunjukkan bahwa model regresi yang diuji dapat dikatakan baik, artinya model yang dihipotesiskan fit dengan data.

Koefisien determinasi dapat dinilai dari besarnya nilai Nagelkerke $R$ Square. Hasil pengujiannya disajikan pada Tabel 4 yaitu sebagai berikut.

Tabel 4.

Hasil Uji Koefisien Determinasi

\begin{tabular}{cccc}
\hline Step & -2 Log likelihood & Cox \& Snell R Square & Nagelkerke R Square \\
\hline 1 & $32,849^{\mathrm{a}}$ & 0,485 & 0,727 \\
\hline
\end{tabular}

Sumber: Data diolah, 2018

Tabel 4 menunjukkan nilai Nagelkerke $R$ Square yaitu sebesar 0,727. Nilai tersebut memiliki arti bahwa variabilitas variabel terikat yang dapat dijelaskan oleh variabel bebas sebesar $72,7 \%$, sedangkan sisanya sebesar $27,3 \%$ dijelaskan oleh variabel-variabel lain diluar model penelitian atau yang tidak dimasukkan dalam penelitian ini.

Matriks klasifikasi menunjukkan kekuatan prediksi dari model regresi untuk memprediksi kemungkinan terjadinya financial distress. Hasil pengujiannya disajikan pada Tabel 5 yaitu sebagai berikut. 
Tabel 5.

Matriks Klasifikasi

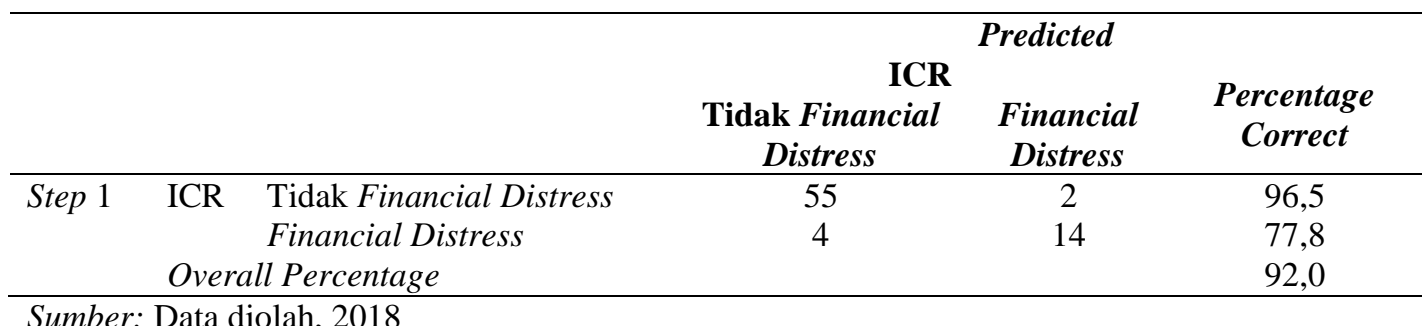

Berdasarkan hasil pengujian matriks klasifikasi pada Tabel 5 kekuatan prediksi dari model regresi untuk memprediksi kemungkinan bahwa perusahaan tidak mengalami financial distress yaitu sebesar 96,5\%. Nilai tersebut menunjukkan bahwa dari 57 total observasi yang tidak mengalami financial distress terdapat 55 total observasi diprediksi tidak mengalami financial distress, sedangkan 2 total observasi diprediksi mengalami financial distress. Kekuatan prediksi dari kemungkinan bahwa perusahaan mengalami financial distress yaitu sebesar $77,8 \%$. Nilai tersebut menunjukkan bahwa dari 18 total observasi yang mengalami financial distress terdapat 4 total observasi diprediksi tidak mengalami financial distress, sedangkan 14 total observasi diprediksi mengalami financial distress.

Model regresi logistik yang terbentuk menghasilkan nilai koefisien regresi dan signifikansi. Hasil pengujiannya disajikan pada Tabel 6.

Tabel 6.

Hasil Uji Regresi Logistik

\begin{tabular}{llcccccc}
\hline & & B & S.E. & Wald & df & Sig. & $\operatorname{Exp(B)~}$ \\
\hline Step $1^{\text {a }}$ & X1 & 0,253 & 0,149 & 2,882 & 1 & 0,090 & 1,287 \\
& X2 & 1,856 & 0,754 & 6,067 & 1 & 0,014 & 6,400 \\
& X3 & $-13,753$ & 4,997 & 7,574 & 1 & 0,006 & 0,000 \\
& X4 & $-2,431$ & 0,938 & 6,720 & 1 & 0,010 & 0,088 \\
& X5 & 0,130 & 0,761 & 0,029 & 1 & 0,865 & 1,138 \\
& Constant & 0,507 & 1,220 & 0,173 & 1 & 0,677 & 1,661 \\
\hline
\end{tabular}

Sumber: Data diolah, 2018

Persamaan model regresi logistik yang dihasilkan yaitu sebagai berikut. 


$$
\operatorname{Ln} \frac{\mathrm{P}}{1-\mathrm{P}}=0,507+0,253 \mathrm{X}_{1}+1,856 \mathrm{X}_{2}-13,753 \mathrm{X}_{3}-2,431 \mathrm{X}_{4}+0,130 \mathrm{X}_{5}+\mathrm{e}
$$

Berdasarkan model regresi yang terbentuk, maka hasilnya dapat diinterpretasikan bahwa nilai konstanta sebesar 0,507 artinya jika variabel rasio likuiditas, leverage, profitabilitas, aktivitas, dan pertumbuhan dianggap konstan maka kemungkinan perusahaan mengalami financial distress akan meningkat sebesar 0,507 .

Koefisien regresi dari variabel rasio likuiditas $\left(\mathrm{X}_{1}\right)$ sebesar 0,253 artinya jika variabel likuiditas meningkat sebesar satu satuan, maka kemungkinan perusahaan mengalami financial distress akan meningkat sebesar 0,253 dengan asumsi bahwa variabel lainnya konstan. Berdasarkan hasil pengujian tersebut, diperoleh nilai signifikansi variabel likuiditas yaitu sebesar 0,090 atau lebih besar dari 0,05 sehingga $\mathrm{H}_{1}$ ditolak. Maka dari itu, dapat disimpulkan bahwa rasio likuiditas tidak berpengaruh pada financial distress. Hasil penelitian ini mendukung penelitian yang dilakukan oleh Sopian dan Putri (2017), Kariani dan Budiasih (2017) serta Dewi dan Dana (2017) yang menemukan bahwa likuiditas tidak berpengaruh pada financial distress. Tidak berpengaruhnya rasio likuiditas dapat disebabkan karena perusahaan pada sampel penelitian dapat dikatakan mampu untuk mendanai operasional perusahaan dalam memenuhi kewajiban jangka pendek yang dimilikinya. Standar rasio industri likuiditas menurut Kasmir (2012: 143) adalah 2,00, artinya setiap 1,00 hutang lancar yang dimiliki perusahaan maka tersedia $200 \%$ aset lancar untuk menutupinya. Data menunjukkan bahwa rata-rata likuiditas perusahaan sampel yaitu sebesar 2,27723 
yang berada diatas rata-rata rasio industri likuiditas sehingga menunjukkan aset lancar perusahaan mampu menutupi kewajiban jangka pendeknya.

Tingkat likuiditas perusahaan tidak dapat menjamin bahwa perusahaan akan mengalami financial distress pada penelitian ini karena current ratio merupakan pengukur likuiditas jangka pendek, sedangkan financial distress merupakan prediksi untuk jangka panjang (Dewi dan Dana, 2017). Disamping itu, nilai current ratio juga sangat bergantung pada jenis usaha dari masing-masing perusahaan. Tingginya nilai current ratio biasanya diakibatkan oleh besarnya jumlah aset lancar yang dimiliki perusahaan seperti persediaan dan piutang usaha, dimana sampel dalam penelitian ini yaitu perusahaan ritel yang tentunya memiliki jumlah persediaan yang cukup besar untuk melakukan kegiatan operasionalnya sebagai pengecer sehingga rasio likuiditas tidak dapat mempengaruhi kemungkinan financial distess khususnya pada sektor usaha ritel. Selain itu, untuk mengubah piutang usaha dan persediaan menjadi dalam bentuk kas guna membiayai kewajibannya diperlukan waktu yang tidak sedikit dan berbeda-beda bagi tiap perusahaan (Kariani dan Budiasih, 2017). Oleh karena itu, dapat disimpulkan bahwa dalam penelitian ini tidak terdapat hubungan yang signifikan antara likuiditas dan financial distress.

Koefisien regresi dari variabel rasio leverage $\left(\mathrm{X}_{2}\right)$ sebesar 1,856 artinya jika variabel leverage meningkat sebesar satu satuan, maka kemungkinan perusahaan mengalami financial distress akan meningkat sebesar 1,856 dengan asumsi bahwa variabel lainnya konstan. Berdasarkan hasil pengujian tersebut, diperoleh nilai signifikansi variabel leverage yaitu sebesar 0,014 atau lebih kecil dari 0,05 
Ni Wayan Agustini dan Ni Gusti Putu Wirawati. Pengaruh...

sehingga $\mathrm{H}_{2}$ diterima. Oleh karena itu, dapat disimpulkan bahwa rasio leverage berpengaruh positif pada financial distress. Hasil penelitian ini mendukung penelitian yang dilakukan oleh Utami (2015), Sari dan Putri (2016), Antikasari (2017) serta Dewi dan Dana (2017) yang menemukan bahwa rasio leverage berpengaruh positif pada financial distress. Rasio leverage menunjukkan kemampuan perusahaan dalam membayar seluruh kewajibannya, baik jangka pendek maupun jangka panjang. Semakin besar rasio leverage suatu perusahaan akan menyebabkan semakin besarnya risiko perusahaan mengalami kesulitan untuk melunasi pokok pinjaman dan biaya bunga akibat jumlah aset yang dimiliki perusahaan tidak mampu menjamin hutang-hutangnya.

Tingginya rasio leverage perusahaan juga akan menyebabkan kurangnya kepercayaan pihak yang berkepentingan terhadap perusahaan seperti kreditur karena perusahaan dengan rasio leverage yang tinggi cenderung mereka hindari untuk berinvestasi akibat rendahnya tingkat perlindungan terhadap pengembalian dana yang dipinjamkan (Brigham dan Houston, 2015: 143). Hal ini akan menyebabkan perusahaan mengalami kesulitan untuk memperoleh dana guna membiayai kepentingan perusahaan sehingga kemungkinan mengalami financial distress semakin besar.

Koefisien regresi dari variabel rasio profitabilitas $\left(\mathrm{X}_{3}\right)$ sebesar $-13,753$ artinya jika variabel profitabilitas meningkat sebesar satu satuan, maka kemungkinan perusahaan mengalami financial distress akan menurun sebesar 13,753 dengan asumsi bahwa variabel lainnya konstan. Berdasarkan hasil pengujian tersebut, diperoleh nilai signifikansi variabel profitabilitas yaitu sebesar 
0,006 atau lebih kecil dari 0,05 sehingga $\mathrm{H}_{3}$ diterima. Oleh karena itu, dapat disimpulkan bahwa rasio profitabilitas berpengaruh negatif pada financial distress. Hasil penelitian ini mendukung penelitian yang dilakukan oleh Noviandri (2014), Dewi dan Dana (2017) serta Muflihah (2017) yang menemukan bahwa rasio profitabilitas berpengaruh negatif pada financial distress. Rasio profitabilitas yang tinggi dapat menunjukkan kemampuan perusahaan dalam menggunakan dan mengelola aset yang dimilikinya secara efektif dan efisien untuk menghasilkan laba sehingga mengurangi biaya yang dikeluarkan perusahaan. Oleh karena itu, perusahaan akan memperoleh penghematan dan memiliki kecukupan dana untuk menjalankan usahanya sehingga terhindar dari financial distress. Sebaliknya, rendahnya nilai rasio profitabilitas suatu perusahaan dapat memungkinkan kinerja perusahaan kurang efektif dalam mengolah aset yang dimiliki untuk menghasilkan laba sehingga dapat menimbulkan kerugian yang berakibat pada arus kas negatif dan perusahaan akan mengalami financial distress.

Koefisien regresi dari variabel rasio aktivitas $\left(\mathrm{X}_{4}\right)$ sebesar $-2,431$ artinya jika variabel aktivitas meningkat sebesar satu satuan, maka kemungkinan perusahaan mengalami financial distress akan menurun sebesar 2,431 dengan asumsi bahwa variabel lainnya konstan. Berdasarkan hasil pengujian tersebut, diperoleh nilai signifikansi variabel aktivitas yaitu sebesar 0,010 atau lebih kecil dari 0,05 sehingga $\mathrm{H}_{4}$ diterima. Maka dari itu, dapat disimpulkan bahwa rasio aktivitas berpengaruh negatif pada financial distress. Hasil penelitian ini mendukung penelitian yang dilakukan oleh Hidayat dan Merianto (2014), Widhiari dan Merkusiwati (2015), dan Antikasari (2017) yang menunjukkan 
Ni Wayan Agustini dan Ni Gusti Putu Wirawati. Pengaruh...

bahwa rasio aktivitas berpengaruh negatif terhadap financial distress. Rasio aktivitas yang diproksikan dengan TATO mengukur sampai seberapa besar efektivitas perusahaan dalam menggunakan sumber dayanya yang berupa aset. Semakin tinggi perputaran total aset menggambarkan semakin efektif total aset perusahaan menghasilkan penjualan. Tingginya rasio ini menunjukkan semakin efisien penggunaan dan pengelolaan aset oleh manajemen sehingga pengembalian dana dalam bentuk kas akan semakin cepat. Sebaliknya, apabila rasio ini rendah maka perusahaan tidak menghasilkan volume penjualan yang cukup dibanding dengan investasi dalam asetnya. Hal ini menunjukkan kinerja yang kurang baik, sehingga dapat mempengaruhi kondisi keuangan sehingga kemungkinan suatu perusahaan mengalami financial distress akan semakin besar.

Koefisien regresi dari variabel rasio pertumbuhan $\left(\mathrm{X}_{5}\right)$ sebesar 0,130 artinya jika variabel pertumbuhan meningkat sebesar satu satuan, maka kemungkinan perusahaan mengalami financial distress akan meningkat sebesar 0,130 dengan asumsi bahwa variabel lainnya konstan. Berdasarkan hasil pengujian tersebut, diperoleh nilai signifikansi variabel pertumbuhan yaitu sebesar 0,865 atau lebih besar dari 0,05 sehingga $\mathrm{H}_{5}$ ditolak. Maka dari itu, dapat disimpulkan bahwa rasio pertumbuhan tidak berpengaruh pada financial distress. Hasil penelitian ini mendukung penelitian yang dilakukan oleh Eminingtyas dan Nita (2017) dan Muflihah (2017) yang menyatakan bahwa rasio pertumbuhan tidak memiliki pengaruh pada financial distress. Hal tersebut dapat dikarenakan oleh perusahaan dengan tingkat pertumbuhan penjualan yang relatif stabil atau tidak berfluktuasilah yang biasanya akan lebih mudah untuk mendapat pinjaman dari 
kreditur dibandingkan perusahaan dengan pertumbuhan penjualan terlalu tinggi atau rendah karena dianggap perusahaan berada dalam kondisi yang stabil. Tidak berpengaruhnya rasio pertumbuhan juga dapat disebabkan karena perusahaan dengan tingkat pertumbuhan penjualan yang tinggi belum tentu memiliki laba yang besar sehingga dapat terhindar dari financial distress. Hal ini disebabkan oleh adanya faktor lain seperti besar kecilnya beban yang dapat berpengaruh pada laba perusahaan.

Perusahaan dengan tingkat penjualan yang tinggi belum tentu memilki beban yang sedikit, dimana jika beban yang dimiliki cukup besar maka dapat menyebabkan laba yang dihasilkan hanya sedikit akibat pendapatan perusahaan telah digunakan untuk menutupi beban perusahaan sehingga kemungkinan perusahaan mengalami financial distress akan semakin besar (Sopian dan Putri, 2017). Melalui hasil analisis statistik deskriptif diperoleh nilai rata-rata pertumbuhan penjualan perusahaan sampel sebesar 0,33064 yang menunjukkan bahwa penjualan perusahaan cukup mengalami pertumbuhan, sedangkan nilai rata-rata rasio profitabilitas sebesar $-0,2694$ yang menunjukkan bahwa kemampuan perusaahaan menghasilkan laba cukup redah atau bahkan mengalami kerugian. Hal ini menunjukkan bahwa pertumbuhan penjualan tidak selalu diikuti dengan kenaikan laba perusahaan. Oleh karena itu, dapat disimpulkan bahwa dalam penelitian ini rasio pertumbuhan tidak berpengaruh pada kemungkinan financial distress. 
Ni Wayan Agustini dan Ni Gusti Putu Wirawati. Pengaruh...

\section{SIMPULAN}

Berdasarkan analisis yang dilakukan terkait dengan pengaruh rasio keuangan pada financial distress, maka dapat disimpulkan bahwa rasio likuiditas tidak berpengaruh pada financial distress perusahaan ritel yang terdaftar di BEI. Rasio leverage berpengaruh positif pada financial distress perusahaan ritel yang terdaftar di BEI. Rasio profitabilitas berpengaruh negatif pada financial distress perusahaan ritel yang terdaftar di BEI. Rasio aktivitas berpengaruh negatif pada financial distress perusahaan ritel yang terdaftar di BEI. Rasio pertumbuhan tidak berpengaruh pada financial distress perusahaan ritel yang terdaftar di BEI.

Berdasarkan hasil penelitian dan kesimpulan yang ada, maka beberapa saran yang dapat diberikan yaitu perusahaan sebaiknya lebih memperhatikan laporan keuangan terutama pada rasio leverage, profitabilitas, dan aktivitas yang terbukti memiliki pengaruh terhadap financial distress serta diharapkan penelitian ini dapat digunakan untuk melakukan tindakan-tindakan pencegahan agar perusahaan terhindar dari financial distress.

Para pengguna laporan keuangan sebaiknya dapat lebih memperhatikan pengungkapan informasi dalam laporan keuangan perusahaan sehingga dapat mengetahui indikasi terjadinya financial distress pada suatu perusahaan. Sebelum mengambil keputusan investasi, calon investor dan kreditur juga perlu mempertimbangkan aspek fundamental seperti rasio keuangan perusahaan.

Penelitian selanjutnya diharapkan dapat menambahkan periode pengamatan dan tidak hanya meneliti financial distress pada perusahaan ritel, namun dapat memperluas sampel perusahaan seperti seluruh perusahaan yang terdaftar di BEI 
serta menambahkan variabel lain di luar rasio keuangan seperti good corporate governance.

\section{REFERENSI}

Al-khatib, H. B., \& Al-Horani, A. (2012). Predicting Financial Distress of Public Companies Listed in Amman Stock Exchange. European Scientific Journal, $8(15), 1-17$.

Altman, E. I. (1968). Financial Ratios, Discriminant Analysis and the Prediction of Corporate Bankruptcy. The Journal of Finance, 23(4), 589-609.

Ananda, N. (2017). 5 Toko Ritel yang Bangkrut Tergerus Toko Online. Diunduh dari https://www.rappler.com/indonesia/berita/186707-5-toko-ritel-bangkruttergerus-toko-online

Antikasari, T. W. (2017). Memprediksi Financial Distress dengan Binary Logit Regression Perusahaan Telekomunikasi. Jurnal Keuangan Dan Perbankan, 2(21), 265-275.

Asquith, P., Gertner, R., \& Scharfstein, D. (1994). Anatomy of Financial Distress : An Examination of Junk-Bond Issuers. The Quarterly Journal of Economics, 109(3), 625-658.

Beaver, W. H., Correia, M., \& McNichols, M. F. (2010). Financial Statement Analysis and the Prediction of Financial Distress. Foundations and Trends in Accounting, 5(4), 99-173.

Brahmana, R. K. (2007). Identifying Financial Distress Condition in Indonesia Manufacture Industry. Journal of Accounting, 5-51.

Brigham, E. F., \& Houston, J. F. (2015). Dasar-Dasar Manajemen Keuangan Essentials of Financial Management. Jakarta: Salemba Empat.

Claessens, S., Djankov, S., \& Klapper, L. (2003). Resolution of Corporate Distress in East Asia. Journal of Empirical Finance, 10, 199-216.

Dewi, N. K. U. G., \& Dana, M. (2017). Variabel Penentu Financial Distress pada Perusahaan Manufaktur di Bursa Efek Indonesia. E-Jurnal Manajemen Unud, 6(11), 5834-5858.

Elloumi, F., \& Gueyie, J.-P. (2001). Financial Distress and Corporate Governance: An Empirical Analysis. Corporate Governance: The International Journal of Business in Society, 1(1), 15-23. 
https://doi.org/10.1108/14720700110389548

Eminingtyas, R., \& Nita, R. A. (2017). Pengaruh Ukuran Perusahaan, Likuiditas, Leverage, Sales Growth dan Operating Capacity terhadap Financial Distress pada Perusahaan Manufaktur (Terdaftar di BEI). Perbanas Institutional Repository, 1-18.

Hanifah, O. E., \& Purwanto, A. (2013). Pengaruh Struktur Corporate Governance dan Financial Indicators terhadap Kondisi Financial Distress. Diponegoro Journal of Accounting, 2(2), 1-16.

Harahap, S. S. (2011). Teori Akuntansi. Jakarta: Rajawali Press.

Hidayat, M. A., \& Merianto, W. (2014). Prediksi Financial Distress Perusahaan Manufaktur di Indonesia. Diponegoro Journal of Accounting, 3(3), 1-11. https://doi.org/ISSN (Online):2337-3806

Jiming, L., \& Weiwei, D. (2011). An Empirical Study on the Corporate Financial Distress Prediction Based on Logistic Model: Evidence from China's Manufacturing Industry. International Journal of Digital Content Technology and Its Applications, 5(6), 368-379. https://doi.org/10.4156/jdcta.vol5.issue6.44

Kariani, N. P. K., \& Budiasih, I. G. A. N. (2017). Firm Size sebagai Pemoderasi Pengaruh Likuiditas, Leverage, dan Operating Capacity pada Financial Distress. E-Jurnal Akuntansi Universitas Udayana, 20(3), 2187-2216.

Kasmir. (2012). Analisis Laporan Keuangan. Jakarta: Rajawali Pers.

Kristanti, F. T., Rahayu, S., \& Huda, A. N. (2016). The Determinant of Financial Distress on Indonesian Family Firm. Procedia - Social and Behavioral Sciences, 219, 440-447. https://doi.org/10.1016/j.sbspro.2016.05.018

Lawrence, J. R., Pongsatat, S., \& Lawrence, H. (2015). The Use Of Ohlson's OScore for Bankruptcy Prediction in Thailand. The Journal of Applied Business Research, 31(6), 2069-2079.

Liana, D., \& Sutrisno. (2014). Analisis Rasio Keuangan untuk Memprediksi Kondisi Financial Distress Perusahaan Manufaktur, 1(2), 52-62.

Muflihah, I. Z. (2017). Analisis Financial Distress Perusahaan Manufaktur di Indonesia dengan Regresi Logistik. Majalah Ekonomi, 22(2), 254-269.

Noviandri, T. (2014). Peranan Analisis Rasio Keuangan dalam Memprediksi Kondisi Financial Distress Perusahaan Sektor Perdagangan. Jurnal iImu Manajemen, 2(4), 1-11. 
Pervan, I., Pervan, M., \& Vukoja, B. (2011). Prediction of Company Bankruptcy Using Statistical Techniques-Case of Croatia. Croatian Operational Research Review, 2(1), 158-167.

Platt, H. D., \& Platt, M. B. (2002). Predicting Corporate Financial Distress: Reflections on Choice-Based Sample Bias. Journal of Economics and Finance, 26(2), 184-199. https://doi.org/10.1007/BF02755985

Pramdia, A. (2017). Perusahaan Ritel Banyak Tutup, Apa yang Sebenarnya Terjadi? Diunduh dari https://ekonomi.kompas.com/read/2017/10/27/184542026/perusahaan-ritelbanyak-tutup-apa-yang-sebenarnya-terjadi

Puspitawati, E. (2016). Implikasi Rasio Lancar dan Rasio Pertumbuhan Penjualan terhadap Prediksi Kesulitan Keuangan (Survei Pebelitian pada Perusahaan Sub Sektor Tekstil dan Garmen yang Terdaftar di Bursa Efek Indonesia Tahun 2012-2016). Unikom Repository, 1-18.

Sari, N. L. K. M., \& Putri, I. G. A. M. A. D. (2016). Kemampuan Profitabilitas Memoderasi Pengaruh Likuiditas dan Leverage terhadap Financial Distress. E-Jurnal Ekonomi Dan Bisnis Universitas Udayana, 10(5), 3419-3448.

Sopian, D. R., \& Putri, W. (2017). Pengaruh Rasio Keuangan dan Ukuran Perusahaan terhadap Financial Distress (Studi Empiris pada Perusahaan Food and Beverage di Bursa Efek Indonesia). Competitive Jurnal Akuntansi Dan Keuangan, 1(2), 1-13.

Ugurlu, M., \& Aksoy, H. (2006). Prediction of Corporate Financial Distress in an Emerging Market: The Case of Turkey. Cross Cultural Management: An International Journal, 13(4), 277-295. https://doi.org/10.1108/13527600610713396

Utami, C. W. (2008). Manajemen Barang Dagang dalam Bisnis Ritel. Malang: Bayu Media Publishing.

Utami, M. (2015). Pengaruh Aktivitas, Leverage, dan Pertumbuhan Perusahaan dalam Memprediksi Financial Distress. Jurnal Akuntansi, 3(1), 1-27.

Whitaker, R. B. (1999). The Early Stages of Financial Distress. Journal of Economics and Finance, 23(2), 123-132. https://doi.org/10.1007/BF02745946

Wiagustini, N. (2010). Dasar-Dasar Manajemen Keuangan. Denpasar: Udayana University Press. 
Ni Wayan Agustini dan Ni Gusti Putu Wirawati. Pengaruh...

Widhiari, N. L. M. A., \& Merkusiwati, N. K. L. A. (2015). Pengaruh Rasio Likuiditas, Leverage, Operating Capity, dan Sales Growth terhadap Financial Distress. E-Jurnal Akuntansi Universitas Udayana, 11(2), 456-469. https://doi.org/ISSN: 2302-8556

Zhou, L., Lai, K. K., \& Yen, J. (2012). Empirical Models Based on Features Ranking Techniques for Corporate Financial Distress Prediction. Computers and Mathematics with Applications, 64(8), 2484-2496. https://doi.org/10.1016/j.camwa.2012.06.003 